\title{
Ethacrynic Acid: Two Years' Experience with a New Diuretic
}

\author{
J. G. G. LEDINGHAM,* M.A., M.R.C.P.; R. I. S. BAYLISS,* M.D., F.R.C.P.
}

Brit. med. F., 1965, 2, 732-735

In 1963 the first clinical reports on ethacrynic acid (2,3dichloro-4-(2-methylene butyryl)phenoxyacetic acid) indicated that this was a new diuretic agent of unique chemical structure, and of potency equivalent to or exceeding that of organomercurial or benzothiadiazine compounds (Foltz, 1963 ; Melvin et al., 1963 ; Cannon et al., 1963 ; Daley and Evans, 1963). Subsequent work has confirmed the early conclusions and shown that ethacrynic acid is exceptionally potent, and is effective in the treatment of oedema of many different causes (Dollery et al., 1964 ; Müller and Schaub, 1964 ; Bourke et al., 1965 ; Maher and Schreiner, 1965 ; Cannon et al., 1965).

Ethacrynic acid combines readily with sulphydryl groups (Beyer et al., 1965), and its action on the renal tubule is to increase urine volume and excretion of sodium, chloride, potassium, and hydrogen ions (Cannon et al., 1963 ; Bourke et al., 1965 ; Ledingham and Bayliss, 1965). There is good evidence that the drug inhibits sodium transport both in the proximal tubule and in the ascending limb of Henle's loop (Goldberg et al., 1964 ; Earley and Friedler, 1964 ; Beyer et al., 1965 ; Ledingham and Bayliss, 1965 ). We have now been using ethacrynic acid for more than two years, the results being reported below.

\section{Methods}

Thirty-three patients with fluid retention of varying degrees of severity have been treated with ethacrynic acid alone or in combination with other diuretics on 38 separate hospital admissions. In seven patients the oedema was caused by cirrhosis of the liver, in four by the nephrotic syndrome, and in 20 by congestive heart failure; in one case the oedema was related to hypoproteinaemia from gastro-intestinal protein loss, and in another to acute nephritis. Six patients were studied under metabolic-balance conditions with a constant daily intake of sodium $(22-44 \mathrm{mEq})$ and of potassium $(38-62 \mathrm{mEq})$. In eight patients dietary sodium and potassium were unrestricted and in the remaining 19 sodium intake was constant $(22-44 \mathrm{mEq})$ and potassium intake variable. Fluid intake was measured daily but was not controlled. Supplements of potassium chloride or bicarbonate were given as required. In 30 of the patients daily 24-hour urine collections were made for estimation of sodium, potassium, and chloride excretion. These patients, and the three in whom urine collections were not made, were weighed at the same time each day. Blood was taken for measurement of serum-electrolyte and blood-urea concentrations at frequent intervals.

The analytic methods used have been described elsewhere (Ledingham and Bayliss, 1965).

\section{Results}

The results have been assessed in terms of the loss of weight or the 24-hour urinary excretion of sodium and potassium on each day that a diuretic was given. Sodium excretion has been defined as excessive if more than $300 \mathrm{mEq}$ in 24 hours; good if between 60 and $300 \mathrm{mEq}$; moderate if between 40 and 60 $\mathrm{mEq}$; and poor if less than $40 \mathrm{mEq}$. In the three patients in

\footnotetext{
* Westminster Hospital and Medical School, London.
}

whom urine collections were not made, loss of weight of more than $2 \mathrm{~kg}$. in 24 hours was defined as excessive, 0.5 to $2 \mathrm{~kg}$. as good, 0.25 to $0.5 \mathrm{~kg}$. as moderate, and less than $0.25 \mathrm{~kg}$. as poor. Potassium excretion has been defined as excessive if more than $80 \mathrm{mEq}$ in 24 hours, moderate if between 40 and $80 \mathrm{mEq}$, and mild if less than $40 \mathrm{mEq}$.

\section{Ethacrynic Acid, Benzothiadiazine, or Mersalyl alone}

Ethacrynic acid was given without other diuretics on 152 days to 30 patients. The dose ranged from 25 to $450 \mathrm{mg}$. a day, and the best responses were obtained when the drug was given twice or thrice daily. The results are shown in Table I. Benzothiadiazine diuretics were given to 22 of the same patients on 115 days in doses ranging from 0.5 to $2 \mathrm{~g}$. daily of chlorothiazide or equivalent dosages of hydrochlorothiazide, hydroflumethiazide, or bendrofluazide. The results of benzothiadiazine therapy are shown in Table II. Seventeen of the same

TABle I.-Urinary Sodium and Potassium Excretion After Various Doses of Ethacrynic Acid in Terms of Days on Which a Given Response was Achieved by Each Dose in a Group of 30 Patients

\begin{tabular}{|c|c|c|c|c|c|c|c|c|c|c|c|}
\hline & \multirow{2}{*}{$\begin{array}{c}\text { Urinary } \\
\text { Excretion } \\
\text { (mEq/ } \\
24 \\
\text { Hours) }\end{array}$} & \multicolumn{10}{|c|}{$\begin{array}{c}\text { No. of Days on which Degree of Urinary Excretion } \\
\text { was Observed } \\
\text { Dose of Ethacrynic Acid (mg./24 Hours) }\end{array}$} \\
\hline & & 25 & 50 & 75 & 100 & 125 & 150 & 200 & 300 & 400 & 450 \\
\hline odium & $\left\{\begin{array}{l}>300 \\
60-300 \\
40-60 \\
<40\end{array}\right.$ & $\frac{-2}{3}$ & $\begin{array}{r}-6 \\
1 \\
\end{array}$ & $\begin{array}{l}\overline{4} \\
1 \\
-\end{array}$ & $\begin{array}{r}\overline{20} \\
7 \\
3\end{array}$ & $\underline{-}$ & $\begin{array}{r}\overline{17} \\
3 \\
6\end{array}$ & $\begin{array}{r}6 \\
16 \\
7 \\
5\end{array}$ & $\begin{array}{r}\overline{26} \\
5 \\
2\end{array}$ & $\begin{array}{l}\overline{1} \\
1 \\
2\end{array}$ & $\begin{array}{c}-1 \\
1 \\
-\end{array}$ \\
\hline otassium & $\left\{\begin{array}{l}>80 \\
40-80 \\
<40\end{array}\right.$ & $\bar{z}$ & $\overline{3}$ & $\begin{array}{r}4 \\
-\end{array}$ & $\begin{array}{r}4 \\
10 \\
16\end{array}$ & $\bar{z}$ & $\begin{array}{r}4 \\
17 \\
5\end{array}$ & $\begin{array}{r}10 \\
19 \\
5\end{array}$ & $\begin{array}{r}9 \\
21 \\
3\end{array}$ & $\overline{2}$ & $\begin{array}{l}1 \\
1 \\
\end{array}$ \\
\hline $\begin{array}{l}\text { otal No. } \\
\text { per d }\end{array}$ & $\begin{array}{l}\text { of days } \\
\text { ose }\end{array}$ & 5 & 7 & 5 & 30 & 1 & 26 & 34 & 33 & 4 & 2 \\
\hline
\end{tabular}

TABLE II.-Urinary Sodium and Potassium Excretion After Various Doses of Benzothiadiazine in Terms of the Number of Days on Which a Given Response was Achieved by Each Dose in a Group Which a Given
of 22 Patients

\begin{tabular}{|c|c|c|c|c|c|}
\hline \multirow{2}{*}{\multicolumn{3}{|c|}{$\begin{array}{c}\text { Urinary } \\
\text { Excretion } \\
(\mathrm{mBq} / 24 \text { Hours })\end{array}$}} & \multicolumn{3}{|c|}{$\begin{array}{c}\text { No. of Days on which Degree of Urinary Excretion } \\
\text { was Observed } \\
\text { Dose of Chlorothiazide (g./24 Hours) }\end{array}$} \\
\hline & & & 0.5 & 1 & 2 \\
\hline Sodium & $\left\{\begin{array}{l}>300 \\
60-300 \\
40-60 \\
<40\end{array}\right.$ & $\begin{array}{l}\ldots \\
\cdots \\
\cdots\end{array}$ & $\begin{array}{r}\overline{11} \\
2 \\
3\end{array}$ & $\begin{array}{l}-8 \\
4 \\
4\end{array}$ & $\begin{array}{l}\overline{28} \\
11 \\
38\end{array}$ \\
\hline Potassium \{ & $\left\{\begin{array}{l}>80 \\
40-80 \\
<40\end{array}\right.$ & \begin{tabular}{l|}
$\cdots$ \\
$\cdots$
\end{tabular} & $\begin{array}{l}2 \\
9 \\
5\end{array}$ & $\begin{array}{l}0 \\
8 \\
8\end{array}$ & $\begin{array}{r}6 \\
34 \\
37\end{array}$ \\
\hline \multicolumn{3}{|c|}{ Total No. of days per dose } & 16 & 16 & 77 \\
\hline
\end{tabular}

TABLE III.-Urinary Sodium and Potassium Excretion After $2 \mathrm{ml}$. of Mersalyl Intramuscularly in Terms of Number of Days on Which a Mersalyl Intramuscularly in Terms of Number
Given Response Was Achieved in 17 Patients

\begin{tabular}{|c|c|c|c|}
\hline & \multicolumn{2}{|c|}{$\begin{array}{l}\text { Urinary Excretion } \\
(\mathrm{mEq} / 24 \text { Hours })\end{array}$} & $\begin{array}{l}\text { No. of Days on which Degree of } \\
\text { Urinary Excretion was Observed }\end{array}$ \\
\hline Sodium & {$\left[\begin{array}{l}>300 \\
60-300 \\
40-60 \\
<40\end{array}\right.$} & $\begin{array}{l}\ldots \\
\cdots \\
\cdots\end{array}$ & $\begin{array}{r}0 \\
22 \\
4 \\
8\end{array}$ \\
\hline Potassium & $\left\{\begin{array}{l}>80 \\
40-80 \\
<40\end{array}\right.$ & $\begin{array}{ll} & \\
\cdots & \end{array}$ & $\begin{array}{r}4 \\
19 \\
11\end{array}$ \\
\hline
\end{tabular}


patients were given mersalyl $2 \mathrm{ml}$. on 39 days, and the results are shown in Table III.

When the effect of ethacrynic acid is compared with that of benzothiadiazines or of organomercurials (Table IV), ethacrynic acid was the most potent. A moderate or good response was observed on $80 \%$ of days after ethacrynic acid, on $66 \%$ after organomercurials, and on $56 \%$ after benzothiadiazines; poor responses were recorded on only $14 \%$ of days after ethacrynic acid compared with $34 \%$ after mercurials or $44 \%$ after benzothiadiazines. An excessive response in terms of a natriuresis exceeding $300 \mathrm{mEq} / 24$ hours or a loss of weight in excess of $2 \mathrm{~kg} . / 24$ hours occurred after ethacrynic acid on 9 (6\%) days, but did not occur after either of the other two diuretics.

TABLE IV.-Percentage of Days on Which the Responses Shown Below Occurred After Treatment with Ethacrynic Acid, Benzothiadiazines, or Mersalyl

\begin{tabular}{|c|c|c|c|}
\hline & $\begin{array}{c}\text { Ethacrynic } \\
\text { Acid }\end{array}$ & $\begin{array}{l}\text { Benzothia- } \\
\text { diazines }\end{array}$ & Mersalyl \\
\hline 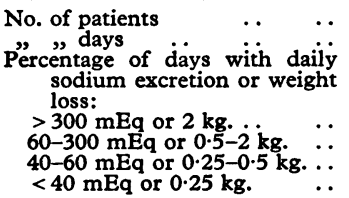 & $\begin{array}{c}30 \\
152 \\
\\
6 \\
62 \cdot 5 \\
17 \cdot 5 \\
14\end{array}$ & $\begin{array}{l}0 \\
41 \\
15 \\
44\end{array}$ & $\begin{array}{r}0 \\
56 \\
10 \\
34\end{array}$ \\
\hline 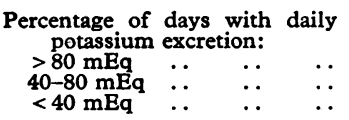 & $\begin{array}{l}21 \\
50 \\
29\end{array}$ & $\begin{array}{r}7 \\
47 \\
46\end{array}$ & $\begin{array}{l}12 \\
56 \\
32\end{array}$ \\
\hline
\end{tabular}

Urinary potassium excretion was greatest after ethacrynic acid, excessive losses as defined above occurring on $21 \%$ of days as compared with $12 \%$ after organomercurials and $7 \%$ after benzothiadiazines.

\section{Ethacrynic Acid or Benzothiadiazines Combined with Spironolactone (Aldactone-A)}

In a group of six patients with resistant oedema, ethacrynic acid in doses of 100 to $400 \mathrm{mg}$. daily was combined with spironolactone 50 to $200 \mathrm{mg}$. daily on 37 days. In three patients the oedema was due to congestive cardiac failure, in two to the nephrotic syndrome, and in one to cirrhosis.

Sodium excretion was excessive on two occasions in one of the cardiac patients when $100 \mathrm{mg}$. of spironolactone was combined with $400 \mathrm{mg}$. of ethacrynic acid. On 21 days the natriuretic response to combined therapy was good, on 10 moderate, and on 4 poor. The poor results were observed after $200 \mathrm{mg}$. of ethacrynic acid and $200 \mathrm{mg}$. of spironolactone on three occasions, and after $150 \mathrm{mg}$. of ethacrynic acid and 50 mg. of spironolactone on another.

With this combination of diuretics excessive loss of potassium occurred on 13 days, moderate loss on 14 days, and excretion was mild (less than $40 \mathrm{mEq}$ daily) on 8 days.

TABLE V.-Percentage of Days on which the Recorded Natriuretic and Kaliuretic Responses Occurred After Treatment with Spironolactone Combined with Ethacrynic Acid or Benzothiadiazine in 10 Patients with Resistant Oedema

\begin{tabular}{l|c|c|c|c|c|c|c|c}
\hline $\begin{array}{c}\text { Diuretic } \\
\text { (mg./day) }\end{array}$ & $\begin{array}{c}\text { No. of } \\
\text { Patients }\end{array}$ & $\begin{array}{c}\text { No. of } \\
\text { Days }\end{array}$ & \multicolumn{3}{c|}{ Percentage of Days with 24-bour Urinary } \\
\cline { 2 - 6 } Excretion of
\end{tabular}

Chlorothiazide or hydroflumethiazide was given in maximum dosage combined with spironolactone $100-200 \mathrm{mg}$. on 38 days, and in half maximum dosage on one day, to a group of four patients with resistant oedema, in two due to the nephrotic syndrome, and in the others to congestive cardiac failure or hepatic cirrhosis. Sodium excretion was never excessive; it was good on 23 days, moderate on 8, and poor on 8 . Potassium excretion was excessive on 7 days, moderate on 15, and mild on 12.

The results of treatment with either ethacrynic acid or benzothiadiazines in combination with spironolactone are shown in Table V. The overall sodium loss was much the same with either ethacrynic acid or benzothiadiazine, but potassium loss was less with benzothiadiazine.

\section{Ethacrynic Acid Combined with Benzothiadiazines}

Ethacrynic acid in doses ranging from 100 to $200 \mathrm{mg}$. daily was combined with chlorothiazide or hydroflumethiazide in maximal doses on 10 days and in half maximal doses on 12 days in eight patients with resistant oedema, due to congestive cardiac failure in five, the nephrotic syndrome in two, and cirrhosis of the liver in one. On all 22 days urinary sodium excretion was good, but urinary potassium loss was excessive on seven occasions (32\%), moderate on $14(63 \%)$, and mild once $(5 \%)$.

\section{Ethacrynic Acid Combined with Benzothiadiazines and Spironolactone}

Full doses of benzothiadiazine diuretic were combined with ethacrynic acid $200 \mathrm{mg}$. daily and spironolactone $200 \mathrm{mg}$. daily on 14 days, and spironolactone $100 \mathrm{mg}$. on four days, in a group of five patients. Fluid retention was caused by congestive heart failure in two, by nephrotic syndrome in two, and by hepatic cirrhosis in one. Good natriuretic responses were obtained on 12 days, moderate on five, and poor on one day in a very ill cardiac patient, who subsequently proved resistant to all combinations of diuretic. Potassium excretion was excessive on four, moderate on 12 , and mild on two occasions.

\section{Other Diuretics Combined with Ethacrynic Acid}

Ethacrynic acid was combined with mersalyl on four occasions; on each the natriuretic response was good, and better than with either drug alone. Ethacrynic acid was not given in maximal dosage, however, on any occasion.

A combination of ethacrynic acid and frusemide was given, using submaximal amounts of both drugs, on seven occasions, on each of which the natriuretic response exceeded that of twice the dose of either drug given singly. Potassium loss was excessive on one occasion, moderate on five, and mild once.

Triamterene was given combined with ethacrynic acid on only three occasions. On none of them was there significant enhancement of sodium excretion, nor was potassium excretion reduced.

\section{Blood-electrolyte Changes}

There was a tendency for the serum concentrations of potassium and chloride to fall and of bicarbonate to rise after each dose of ethacrynic acid given alone or in combination, particularly if the urinary response was good or excessive in terms of sodium excretion or loss of weight. On 11 occasions in seven patients the serum-potassium concentration fell below $3.5 \mathrm{mEq} / 1$. and the bicarbonate concentration rose above 30 $\mathrm{mEq} / \mathrm{l}$. In every instance urinary potassium excretion after ethacrynic acid had been high, exceeding $120 \mathrm{mEq} / 24$ hours on 
five occasions, with the highest rate $240 \mathrm{mEq} /$ day and the lowest $60 \mathrm{mEq} /$ day. On five occasions there was a particularly marked chloruresis, with 24-hour urine-chloride losses exceeding those of sodium by 128 to $325 \mathrm{mEq}$.

The most severe electrolyte disturbances were observed in the first two patients to be given the drug, and the relevant data are shown in the Chart. Potassium supplements had not been given and neither patient showed symptoms other than drowsiness during the biochemical disturbance. After experience with these two cases, supplements of potassium chloride were given with ethacrynic acid, but they were not always completely successful in preventing hypochloraemic hypokalaemic alkalosis. When supplements were given, urine potassium loss increased pari passu, and in one patient, despite added potassium chloride of $120 \mathrm{mEq}$ daily, a single day's treatment with two 50-mg. doses of ethacrynic acid induced such kaliuresis that the serum potassium fell from 4.3 to $2.6 \mathrm{mEq} / \mathrm{l}$. with a coincident rise in serum bicarbonate from 23 to $32 \mathrm{mEq} / 1$. Supplements were well retained when subsequently given on alternate days with ethacrynic acid.

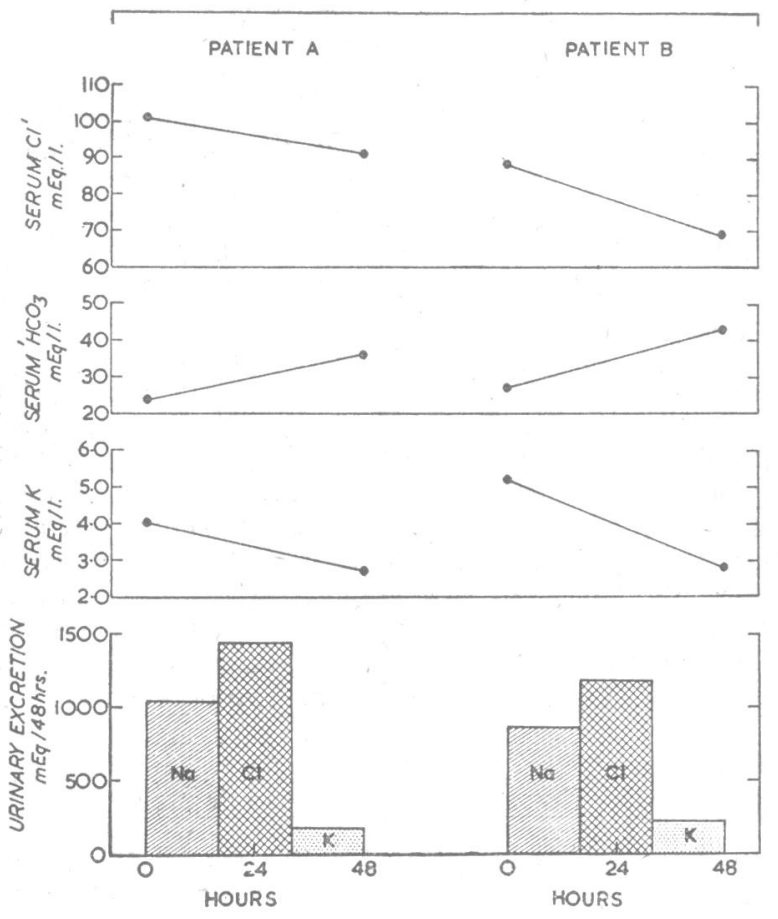

Urinary electrolyte excretion and serum-electrolyte levels in two patients with hepatic cirrhosis before and after treatment with $50 \mathrm{mg}$. of ethacrynic acid six-hourly for 48 hours. Both patients responded well, but chloride excretion exceeded sodium loss and hypochloraemic hypokalaemic alkalosis developed.

\section{Side-effects}

As may occur with any potent diuretic, several patients experienced fatigue after the diuresis induced by ethacrynic acid. The drug was well tolerated and there was little gastric disturbance provided the tablets were given with or after food. Two patients developed agranulocytosis during treatment and died ; both were taking other drugs known to cause depression of the white cells, and both were in the terminal stages of their illness, in one case systemic lupus erythematosus and in the other ischaemic heart disease. No other patients developed depression of the white corpuscles, and none showed abnormalities of liver-function tests.

\section{Discussion}

Ethacrynic acid is best given in divided doses two or three times daily after. food. Our experience shows that it is much more potent than either organomercurial diuretics or benzothiadiazines, but individual patients were encountered in whom the response was better with the older-established agents. In most cases the increased potency of ethacrynic acid was reflected in a response from previously resistant patients or by a better response without troublesome side-effects. However, on 11 occasions out of a total of 244 on which the drug was given the diuretic and natriuretic responses were excessive, with a considerable liability to the development of severe degrees of hypokalaemic and hypochloraemic alkalosis. Such results were observed after submaximal doses of ethacrynic acid and could not be predicted from the previous response to other diuretics. As has been observed by Cannon et al. (1965), the effectiveness of ethacrynic acid tends to remain constant in any given patient, and can be predicted from the six-hour response to a single dose of $50 \mathrm{mg}$. We therefore recommend that, in order to determine the correct dose and to avoid excessive loss of fluid and electrolytes, a preliminary assessment of the six-hour response be made to one dose of $50 \mathrm{mg}$.

Loss of potassium after ethacrynic acid is in many cases similar to that after benzothiadiazines, but sometimes excessively large amounts are excreted. Chloride excretion is also greater, and potassium supplements, obligatory whenever ethacrynic acid is prescribed, are therefore better given as the chloride rather than as the bicarbonate salt. Such supplements may not always prevent hypochloraemic hypokalaemic alkalosis, but this can be corrected, if it arises, by giving ethacrynic acid intermittently and potassium chloride daily. High rates of urinary potassium excretion were still observed on those occasions when ethacrynic acid was combined with spironolactone or triamterene. These combinations were, however, given only to patients with resistant oedema, in whom a high degree of secondary hyperaldosteronism would be expected, and Cannon et al. (1965) have shown that urinary potassium loss after ethacrynic acid is considerably influenced by the rate of endogenous aldosterone production. It is probable, therefore, that spironolactone or triamterene may be more effective in reducing potassium excretion with ethacrynic acid if the combination is given to less-resistant cases of oedema ; however, such patients when treated with ethacrynic acid alone would be expected to respond well without biochemical abnormalities developing when given potassium-chloride supplements, or to be managed successfully with the older-established diuretic agents.

The high incidence of hypokalaemia and hypochloraemia with a raised serum-bicarbonate level after ethacrynic acid therapy is related not only to the potassium depletion but also to excessive urinary loses of chloride and hydrogen ions (Cannon et al., 1965 ; Ledingham and Bayliss, 1965). The disturbance is apparently symptomless and correctable with potassium chloride, nor does it decrease the patient's responsiveness to ethacrynic acid in the same way that hypochloraemic alkalosis renders the patient refractory to organomercurials (Stock et al., 1951).

On the basis of our experience ethacrynic acid is not recommended as the diuretic of first choice, for the very reason of its great potency and because of the need for frequent checking of the serum-electrolyte concentrations and of the white-cell count, although this last may prove unnecessary with continued experience.

On the other hand, ethacrynic acid is particularly recommended for the the treatment of patients resistant to conventional diuretics, in whom the new diuretic given alone is usually successful. All our patients who were resistant to ethacrynic acid by itself responded well to the combination of ethacrynic acid and benzothiadiazine, which in our experience is the most potent regimen available and which does not lead to urinary potassium losses any greater than those induced by ethacrynic acid alone. The new diuretic in submaximal doses also induced an additive effect on the few occasions when it was given with organomercurials or frusemide. 


\section{Summary}

Ethacrynic acid is an effective diuretic in doses ranging from 25 to $450 \mathrm{mg}$. daily. It is more potent than either organomercurial or benzothiadiazine diuretics. An excessive diuresis may occur after ethacrynic acid, and a test dose is recommended for patients new to the drug. Benzothiadiazines given with ethacrynic acid formed the most potent combination of diuretics tried.

Urinary potassium losses are greater after ethacrynic acid than after benzothiadiazines. In resistant cases spironolactone (Aldactone-A) given with ethacrynic acid did not prevent high rates of potassium excretion. Potassium chloride supplements are desirable whenever ethacrynic acid is prescribed, alone or in combination with potassium-sparing agents. The incidence of hypochloraemic hypokalaemic alkalosis is discussed.

Agranulocytosis was observed in two patients, but the causal relationship was not established with any certainty.

Ethacrynic acid is best used in the treatment of patients with resistant oedema: in such cases we have found it invaluable.

Part of this work was done when J. G. G. Ledingham was in receipt of a Leverhulme Research Fellowship at the Institute of
Clinical Research, and especial thanks are expressed to Dr. J. D. N. Nabarro for encouragement and advice at that time. We are grateful to Dr. J. J. F. Merry, of Messrs. Merck Sharp and Dohme, for supplies of ethacrynic acid.

\section{REFERENCES}

Beyer, K. H., Baer, J. E., Michaelson, J. K., and Russo, H. F. (1965). 7. Pharmacol., 147, i.

Bourke, E., Counihan, T. B., Keelan, P., and Ryan, M. (1965). J. Irish

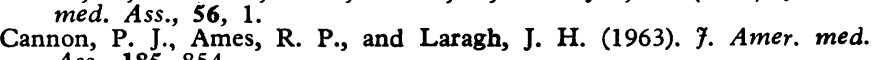
Ass., 185, 854.

Heinemann, H. O., Stason, W. B., and Laragh, J. H. (1965). Circulation, 31, 5 .

Daley, D., and Evans, B. (1963). Brit. med. F., 2, 1169.

Dollery, C. T., Parry, E. H. O., and Young, D. S. (1964). Lancet, 1, 947. Earley, L. E., and Friedler, R. M. (1964). Э. clin. Invest., 43, 1495.

Foltz, E. L. (1963). Fed. Proc., 22, 598.

Goldberg, M., McCurdy, D. K., Foltz, E. L., and Bluemle, L. W. (1964) f. clin. Invest., 43, 201.

Ledingham, J. G. G., and Bayliss, R. I. S. (1965). Clin. Pharmacol. Ther., 6, 474.

Maher, J., F., and Schreiner, G. E. (1965). Ann intern. Med., 62, 15.

Melvin, K. E. W., Farrelly, R. O., and North, J. D. K. (1963). Brit. med. f., 1,1521

Müller, P., and Schaub, F. (1964). Klin. Wschr., 42, 958.

Stock, R. J., Mudge, G. H., and Nurnberg, M. J. (1951). Circulation, 4, 54 .

\title{
Maternal and Neonatal Listeriosis: Report of Case and Brief Review of Literature of Listeriosis in Man
}

\author{
MARY BARBER,* M.D., F.C.PATH. ; O. A. OKUBADEJO, † M.B., B.S., D.C.P.
}

[Wirh Special Plate]

Brit. med. F., 1965, 2, 735-738

Listeria monocytogenes, 40 years after its first isolation and description by Murray, Webb, and Swann (1926), remains, at least for the epidemiologist, a baffling microbe (see Gray, 1963). Animals, birds, and humans are all susceptible to infection, but in view of its widespread distribution in nature such infections are relatively rare and the mode and source of infection are in nearly all cases obscure.

In humans, infection usually takes the form of meningitis, " infectious mononucleosis," or a septicaemic condition of the foetus or newborn infant usually referred to as granulomatosis infantiseptica. In some parts of the world, notably Germany (Potel, 1958) and the United States (Seeliger and Cherry, 1957), the latter appears to be the most frequent form of infection and several recent reports suggest that genital infection with Listeria monocytogenes may be a cause of repeated abortion (Rappaport et al., 1960 ; Gray, 1960 ; Dungal, 1961 ; Toaff et al., 1962).

In Britain, until recently, the disease not only appeared to be more rare than in many other places but of the 11 cases reported in medical journals all but one (Webb, 1943) were meningeal infections (see Beck, 1961). Since 1961 three further cases, all meningitis, have been reported in medical journals (McKinnon and Swithinbank, 1961 ; Harding and Brunton, 1962), bringing the total to 14 . In addition the weekly report of the Public Health Laboratory Service has recorded an increasing number of cases of listeriosis since 1961, and in the first six months

* Professor Barber, who died on 12 September 1965, was Professor of Clinical Bacteriology at the Postgraduate Medical School of London. An obituary notice was printed in the B.M.F. of 18 September (p. 707). t Registrar, Department of Bacteriology, Postgraduate Medical School of
London. of 1965 the number is already eight, but again all the infections have been meningeal. Although five of the 13 fully reported meningeal infections were neonatal (Edmunds et al., 1957 ; Barrow and Pugh, 1958 ; Moore and Whitmore, 1960 ; Harding and Brunton, 1962), in only one was there any suggestive evidence that infection was from the mother (Barrow and Pugh, (1958), and this was unproved. The case reported here represents, therefore, the first bacteriologically confirmed infection in both mother and infant recorded in Britain, although even in this case the patient was not British. Moreover, although Listeria monocytogenes has been isolated from the vagina in patients with a history of abortion (Rappaport et al., 1960) the authors do not know of another case where the organism has been isolated from a septicaemic infection in a pregnant woman and subsequently in the newborn infant.

\section{Case Repont}

\section{History and Clinical Findings}

The patient, a Ghanaian woman aged 21, who had arrived in England three weeks previously, was admitted to this hospital on 21 April 1965. She was 28 weeks pregnant and gave a history of cough associated with scanty blood-stained sputum and upper abdominal pain for eight days, and fever for two days. She had had malaria four years previously and had been taking suppressive therapy until three weeks before admission. She had had a normal pregnancy and delivery in 1960 and the child was alive and well.

On admission the temperature was $102^{\circ} \mathrm{F}$. $\left(38.9^{\circ} \mathrm{C}\right.$.) and bloodpressure $120 / 80 \mathrm{~mm}$. Hg. No signs of abnormality were detected in the chest, cardiovascular system, abdomen, or central nervous 